\title{
Academic Jealousy Scale: Validity and Reliability Study
}

\author{
Duygu KOÇAK *
}

\begin{abstract}
This study aims to develop a measurement tool to determine the level of academic jealousy. For this purpose, firstly, the literature was examined, and a theoretical framework was formed, and then an item set of 47 items was created. The items that were submitted to expert opinion were eliminated and corrected, and 41 items were decided to use, and a trial form was obtained. In this study, 478 university students were reached. One-on-one interviews were conducted with ten students who are studying at Alanya Alaaddin Keykubat University before the trial application. Then, the trial form was applied to 254 university students, and the data obtained were analyzed with Exploratory Factor Analysis, and as a result of this analysis, a structure with three factors (maturity, self-denigration, and envy) was revealed. In order to test the defined structure, the final form of the scale was applied to another group of 154 people, and the data obtained were subjected to Confirmatory Factor Analysis, and goodness of fit indices of the scale was found to be between good fit or acceptable fit. Accordingly, the structure with 19-item and three factors was confirmed Cronbach Alpha internal consistency coefficient of the whole scale was found .779, Envy subfactor was found .840; self-denigration subfactor was found .840 and Maturity subfactor was found .817 . In order to determine the reliability of the scale in terms of stability, the scale was applied to a different group of 57 people at two-week intervals, and the correlation between the two applications was recorded as .89. It was concluded that the Academic Jealousy Scale developed according to these findings, is a valid measurement tool and will give reliable scores in measuring academic jealousy.
\end{abstract}

Key Words: Jealousy, envy, academic jealousy, academic achievement, scale development.

\section{INTRODUCTION}

Jealousy is a concept that is dealt with in many areas such as psychology, sociology, anthropology, especially in emotional relations between people (Pines \& Aronson, 1983). It is known that the first theoretical study on jealousy was made by Lewin (1948), and it was an emotion or behavior that came up, especially in the relationships between married couples. Pines (1998) described jealousy as a response to a hazard element that could lead to the breakdown or end of a valued relationship. In a relationship, the emotional state resulting from the relationship of the person's partner with another person (Buunk \& Bringle, 1987; White, 1981), feelings of anger, unhappiness and fear caused by the deterioration or end of the relationship (DeSteno \& Salovey, 1996) definitions were made. It can be said that jealousy is often defined as the reaction to the possibility of an end to a relationship as a result of the presence of a competitor in an emotional relationship or a marriage (Buunk, Angleitner, Oubaid \& Buss, 1996; Mathes \& Severa, 1981).

All these definitions explain jealousy as a reaction to the possibility of ending or ending the relationship based on an emotional relationship situation. Pines and Bowes (1992) state that jealousy is a complex set of emotions and is extremely painful for most people. There are also various approaches to cause jealousy. For example, Mead (1977) argues that jealousy results from feelings of insecurity and inadequacy of cultural or individual origin. Greenberg and Pyszczynski (1985) state that love, low self-esteem, fear of losing, and insecurity are at the basis of jealousy. Freud, on the other hand, made four different explanations of the basis of jealousy (Pines, 1998): the sadness of the fear of the loss of the loved one, the realization that we could not have everything we wanted (painful awareness), the feelings of envy for successful opponents and the self-indulgence of feeling responsible for losing ourselves. It is seen that Freud pointed to a different point in his statement about jealousy. It shows that envy against successful opponents. Although the concept of envy is similar to

\footnotetext{
* Assist. Prof. PhD., Alanya Alaaddin Keykubat University, Faculty of Education, Antalya-Turkey, duygu.kocak@alanya.edu.tr, ORCID ID: 0000-0003-3211-0426
}

To cite this article:

Koçak, D. (2019). Academic jealousy scale: Validity and reliability study. Journal of Measurement and Evaluation in Education and Psychology, 10(4), 467-479. doi: 10.21031/epod.566752 
jealousy in daily life, it has significant similarities to jealousy in emotional relationships. However, it is different because it is aimed at something that is not owned and a perceived opponent.

Jealousy refers to an individual wants to have what other people have, the individual compares the material opportunities, success, physical characteristics of others with his own, and ultimately the superiority or quantity of someone else, and ultimately, describes a situation where the individual cannot accept the quality or quantity of someone else superior to themself (Anderson, 2002; Kim \& Hupka, 2002; Parrott \& Smith, 1993; Pines, 1998). While in jealousy, the individual reacts to maintain a relationship that he or she has, in case of envy, the individual wants a situation that he or she does not have (Pines \& Aronson, 1983). One of the main differences between jealousy and envy is that jealousy involves three people, not two people as envy. An individual can envy others and aim at what other people have; property, beautiful eyes, personality traits, success, and so on. The focus of envy is an object or property. The focus of jealousy is a third person who is perceived as a threat to the existing relationship (Brehm, 1992; Friday, 1985; Pines, 1998; Salovey \& Rodin, 1986). According to Spielman (1971), envy is the desire of the individual to have what another person has, and the unhappiness and feeling of badness are given by something that someone else has what she or he wants to have. According to this, envy shows itself with the anger and sadness of not having.

Salovey and Rodin (1986) made the difference between jealousy and envy by defining social relationship jealousy and social comparison jealousy. Accordingly, the reaction of an individual's relationship with another person (this can also be an object) is threatened by another person is social relationship jealousy. This can be considered as a reaction to the risk of something that an individual has; it is taken away. What is owned can be a relationship, home, car, success, professional position, but it is often defined as a reaction to the risk of loss or break down of an emotional relationship. In jealousy of social comparison, there is the relationship, professional position, success, home, car, personality trait, or physical trait that the individual wishes to possess, and is the effort to be nurtured and replaced by another person who has this condition. Although both definitions are called jealousy in daily life, it can be stated that social relationship jealousy corresponds to jealousy and social comparison jealousy corresponds to envy.

When definitions of jealousy and envy are examined, it is seen that both concepts are directly related to each other. One concept is the tendency to protect something that is owned, and the other is the tendency to obtain something that does not. With X and Y persons and object A, these two concepts can be summarized as follows: Person X has A and knows that $Y$ wants to have A. In this case, X's sense of protecting A from Y is jealousy. Person Y wants to have A, but X owns it. In this case, Y's aim and reaction to obtain $\mathrm{A}$ from $\mathrm{X}$ is envy. Jealousy and envy involve complex emotions experienced during these desires to obtain or not to lose something. Various studies and scales are found in the literature in order to reveal these complex emotions and the variables they are associated with, especially in order to measure jealousy in emotional relationships. With the scales such as Cognitive Distortions Related to Relationships developed by Hamamc1 (2002), Multidimensional Jealousy Scale was developed by Pfeiffer and Wong (1989) and was adapted into Turkish by Karakurt (2001), Emotional Jealousy Scale was developed by Kızıldağ (2017), Partner Emotional Jealousy Scale was developed Kızıldağ and Yıldırım (2017), jealousy, especially in emotional relations, was tried to be defined and measured.

Although jealousy comes to mind when jealousy is mentioned, one of the critical points in this regard is the concepts of jealousy and envy among individuals encountered in education. The envy for successful opponents and the self-criticism that led us to hold ourselves responsible for being lost constitute which was mentioned in Freud's statement of jealousy are an essential and frequently encountered dimension of jealousy (Pines, 1998). Massé and Gagné (2002) found that the students who successfully stand out from their peers were jealoused by their peers (they describe it as a jealousy corresponding to the concept of envy) and they showed that students were jealous of their peers' social and academic achievements depending on their academic achievement or intelligence. Rentzsch, Schröder-Abé and Schütz (2015) showed that students develop a sense of hostility towards others with academic self-esteem, especially in competitive environments, and the envy mediates this. GonzálezNavarro, Zurriaga-Llorens, Tosin-Olateju, and Llinares-Insa (2018) have demonstrated that envy 
governs interpersonal relationships in working and competitive environments. In these limited numbers of studies, it was seen that qualitative approaches were used to measure envy or the sense of jealousy, and there was no quantitative measurement tool to measure the state of jealousy encountered in academic settings in the literature.

Today, within the number of educational institutions and university graduates increase each year, it is thought that there is competition in both educational institutions and professional institutions, and this will bring the concept of envy. The research results support this. When the studies which were done and the measurement tools which are used are examined, it is seen that there is not a measurement tool to directly reveal academic jealousy. The indirect consequence of this is the theoretical framework for the concept of academic jealousy could not be developed. Many measurement tools to measure emotional jealousy provide to definition of this feature and investigate of the relationship between variables that may be related. Therefore, theories about jealousy in emotional relations have been developed. The lack of a measurement tool to measure academic jealousy in the literature, it was cause that this feature has not been investigated. The use of the scale by researchers is an important starting point in terms of defining the concepts and structures to which the structure is related. In other words, being able to measure the concept of academic jealousy with a measurement tool will also provide to determine the other structures in which it is associated and characteristics of the structure. For this reason, it is thought that the scale plays an important role in the development of the theoretical structure of academic jealousy. Determining an individual's level of academic jealousy will make it easier to determine how this trait will affect one's academic achievement, course of education, peer relationships, and other academic situations. In this sense, the use of the academic jealousy scale by the guidance units in schools is important in terms of recognizing the students and being able to consult them accordingly.

\section{Purpose of the Study}

Although the concept of jealousy is frequently examined in the literature, there is no theoretical study on the concept of academic jealousy. At the same time, the existence of many measurement tools to measure the concept of jealousy, especially in emotional relationships, is the basis for the development of the relevant theoretical structure. As a reason why the theoretical structure of the concept of academic jealousy is not defined, it can be considered that there is no measurement tool for measuring the related structure. In this respect, the primary purpose of this research is to develop the scale of academic jealousy. With this primary purpose, it is aimed to form the basis of the theoretical infrastructure related to the concept of academic jealousy. Accordingly, in this study, determining the indicators related to the concept of academic jealousy and developing the measurement tool are forming the basis of the research.

\section{METHOD}

This study is a descriptive study in which the validity and reliability analyses of Academic Jealousy Scale were conducted and the psychometric properties of academic jealousy were determined.

\section{Working Groups}

The study group of this study consists of 478 students who studied at Alanya Alaaddin Keykubat University in the Fall Semester of 2018-2019 Academic Year selected by random sampling method. Four different study groups were formed at the data collection stage. The first study group was determined to reveal how the items were understood by the students during the writing phase of the scale items. One-on-one interviews were conducted with ten students. Before the item pool was generated, the students in this study group wrote an essay about their feelings and behaviors in case of academic jealousy. The second study group consisted of 254 students who participated in the application of pre-testing after writing the scale items. The data obtained from this application were 
used for Exploratory Factor Analysis (EFA) and reliability calculations in terms of internal consistency. The information about the participants in the second study group is presented in Table 1.

Table 1. Information About the Participants in the Second Study Group

\begin{tabular}{|c|c|c|c|c|c|c|}
\hline & Grade & $\begin{array}{l}\text { Faculty of } \\
\text { Education }\end{array}$ & $\begin{array}{r}\text { Vocational } \\
\text { School } \\
\end{array}$ & $\begin{array}{r}\text { Faculty of } \\
\text { Engineering }\end{array}$ & $\begin{array}{r}\text { Faculty of } \\
\text { Management }\end{array}$ & $\begin{array}{l}\text { School of } \\
\text { Medicine }\end{array}$ \\
\hline \multirow[t]{4}{*}{ Female } & 1. & 24 & 6 & 1 & - & 5 \\
\hline & 2. & 50 & 8 & 7 & 9 & - \\
\hline & 3. & 21 & - & 1 & 17 & - \\
\hline & 4. & 5 & - & - & - & - \\
\hline \multirow[t]{4}{*}{ Male } & 1. & 5 & 2 & 1 & 1 & 1 \\
\hline & 2. & 30 & 14 & 9 & 8 & 5 \\
\hline & 3. & 16 & - & 2 & 6 & - \\
\hline & 4. & 2 & - & - & 2 & - \\
\hline
\end{tabular}

A total of 254 students who are studying at different faculties and vocational schools and at different grade levels consist of the second study group of the present study. EFA was applied to the data obtained from the second study group in order to determine the construct validity of the scale. In addition, the data obtained from the second study group were used to determine the reliability of the scale and its sub-factors in terms of internal consistency and to calculate item discrimination values.

The third study group was formed to determine the reliability of the scale in terms of stability and consisted of 57 people. Information about the participants in the third study group is presented in Table 2 .

Table 2. Information About the Participants in the Third Study Group

\begin{tabular}{lrr} 
& Grade 2 & Grade 4 \\
\hline Female & 14 & 18 \\
Male & 9 & 16 \\
\hline
\end{tabular}

Table 2 provides information about the students in the third study group. In order to determine the reliability of the scale in terms of stability, a total of 57 students who are studying at the Faculty of Education and not in the first group were determined as the third study group.

The fourth study group consisted of 157 students who were reapplication done to confirm the structure, which was determined by EFA. The data obtained from this group were analyzed by Confirmatory Factor Analysis (CFA). Information about the participants who are in the fourth study group is given in Table 3.

Table 3. Information About the Participants in the Fourth Study Group

\begin{tabular}{|c|c|c|c|c|c|c|}
\hline & Grade & $\begin{array}{l}\text { Faculty of } \\
\text { Education }\end{array}$ & $\begin{array}{r}\text { Vocational } \\
\text { School } \\
\end{array}$ & $\begin{array}{r}\text { Faculty of } \\
\text { Engineering }\end{array}$ & $\begin{array}{r}\text { Faculty od } \\
\text { Management }\end{array}$ & $\begin{array}{l}\text { School of } \\
\text { Medicine }\end{array}$ \\
\hline \multirow[t]{4}{*}{ Female } & 1. & 10 & 2 & 5 & 10 & 8 \\
\hline & 2. & 4 & 13 & 5 & 5 & - \\
\hline & 3. & - & - & 3 & 7 & - \\
\hline & 4. & 5 & - & 4 & 2 & - \\
\hline \multirow[t]{4}{*}{ Male } & 1. & 6 & 3 & 9 & 4 & 7 \\
\hline & 2. & 5 & 6 & 7 & 4 & 2 \\
\hline & 3. & - & - & 10 & 6 & - \\
\hline & 4. & - & - & 2 & 3 & - \\
\hline
\end{tabular}

Table 3 provides information about the students who are in the fourth working group. In order to test the structure obtained with the scale, a total of 157 students were identified as the fourth study group. 
The responses of 4 participants were excluded from the analysis due to they create extreme value in the data set. For this reason, CFA was applied with data of 153 people.

\section{Process}

In the development phase of the scale, firstly the theoretical framework was formed by examining the literature and provided 10 students who are in the first study group of the study write a composition about how do you feel if your friends get higher scores, perform better or be more successful than you, on issues like exam results, participate to lesson and academic achievement. The written statements of the students were taken into consideration in the creation of the scale items. There is no scale related to academic jealousy in the literature. For this reason, the theoretical structures about envy and jealousy were examined, and items that may be indicative of academic jealousy are written. According to this, a total of 47 items were written. The opinions of one expert in the field of psychology, two experts in the field of guidance and psychological counseling were consulted, and three items were excluded from the scope on the grounds that they could not measure academic jealousy. Then, the opinions of three different measurement and assessment experts were consulted, and two more items were excluded from the scale because they measured both emotional and behavioral dimensions. Necessary arrangements were made in line with the recommendations, and a total of 41 items were decided. Finally, based on the opinion of one Turkish language expert, the items were checked for grammatical rules. The items were asked by one-on-one interviews with 10 participants in the first study group and how the items were understood was determined, and the requisite modifications were done. This process provided significant findings to determine the structural validity of the items in the scale.

The experimental form was applied to 254 students who were in the second study group, and the data obtained from the second study group were analyzed with CFA in order to define the structure statistically. In addition, item statistics were determined, the final version of the scale was decided considering the theoretical structure, and the internal consistency of the scale was estimated. In order to strengthen the evidence about the reliability of the scale, the reliability in the test-retest of the scale was determined by applying the scale to 57 students who are in the third study group twice in two weeks interval. One more evidence of the structural validity of the scale was obtained by confirming the structure. A total of 153 students who were in the fourth study group were applied the final form of the scale and CFA was applied to the data. The accuracy of the structure created in this way has been tested.

In the development phase of the scale, the literature review was conducted in order to determine criterion validity and whether a scale which proven reliability and validity and developed or adapted to Turkish to measure similar or opposite structures was investigated. However, although the concept of jealousy in emotional relations is a frequently discussed issue, academic jealousy has not been the subject of research. For this reason, criterion-based validity could not be determined due to the insufficiency of the literature, and only construct validity and content validity were investigated.

\section{Data Analysis}

Expert opinion was consulted to determine the content validity of the scale. In order to determine the construct validity, how the items were understood by students was examined. For this purpose, ten students were interviewed about the intelligibility of the items. As statistically evidence was presented about structural validity with EFA and CFA. In the EFA process, Horn's Parallel Analysis method was used in addition to the $\mathrm{K} 1$ rule, which is known to as eigenvalue above 1, in determining the factor number of the scale. Cronbach Alpha was used to determine the reliability of the scale in terms of internal consistency, and in order to determine the reliability in terms of stability, the relationship between the data obtained by the test-retest method was determined by Pearson Product Moment Correlation Coefficient.

Before performing the data analysis, the missing value was examined in the obtained data. The total missing value rate was approximately $2 \%$ in the second study group, $0 \%$ in the third study group, and 
approximately $1.5 \%$ in the fourth study group. Massing values were completed by ExpectationMaximization Algorithm method due to the method performs well in case of low percentage of missing data in every missing data mechanism (Koçak \& Çokluk-Bökeoğlu, 2017). Then, the extreme value analysis was performed, and four participants in the fourth study group were excluded from the analysis due to their extreme values. The normality of the data sets was tested, and the analysis process was initiated. Lisrel 8.51 program was used for DFA. Other analyses were performed using "psych" package in $\mathrm{R}$ program.

\section{RESULTS}

In this section, firstly, findings related to EFA, then findings related to CFA, and finally, findings related to reliability of the scale are given. In the process of obtaining the findings, the first EFA was performed. Before evaluating the results of EFA, it is necessary to examine whether the data are suitable for factor analysis. Whether the data are suitable for EFA can be explained by Kaiser-MeyerOlkin (KMO) and Bartlett Sphericity Test (Çokluk, Şekercioğlu \& Büyüköztürk, 2012). KaiserMeyer-Olkin (KMO) coefficient and Bartlett Sphericity test results obtained in accordance with this requirement are presented in Table 4.

Table 4. KMO and Bartlett Sphericity Test Results

\begin{tabular}{lll}
\hline Sample Value of Kaiser-Meyer-Olkin & .837 \\
\hline Bartlett Sphericity Test & Approximate Chi-Square & 1444 \\
\cline { 2 - 3 } & Degree of freedom & 171 \\
\cline { 2 - 3 } & Significance level & .000 \\
\hline
\end{tabular}

In accordance with the values presented in Table 4, it was decided that the data were suitable for factor analysis. Field (2000) states that the Kaiser-Meyer-Olkin value should be above .50. A three-factor structure was obtained as a result of EFA. Information about the factors is given in Table 5.

Table 5. Results Related about Number of Factors and Total Variance Explained

\begin{tabular}{lrrr}
\hline Factors & Eigenvalue & $\mathbf{( \% )}$ of Variance & Total Variance Explained \\
\hline Factor 1 & 4.989 & 26.259 & 48.007 \\
Factor 2 & 2.603 & 13.698 & \\
Factor 3 & 1.529 & 8.050 & \\
Factor 4 & 0.998 & 5.250 & \\
Factor 5 & 0.980 & 5.156 & \\
\hline
\end{tabular}

In Table 5, the factors obtained as a result of EFA, the variance explained by the factors, and the total variance ratio explained by three factors with an eigenvalue above 1 are presented. To accept factors with eigenvalues above 1 as determinative factors are called the K1 rule (Çokluk \& Koçak, 2016). According to this method, factors with eigenvalues above 1 were accepted as valid factors. A total variance ratio between 40 and 60 percent is accepted as ideal (Scherer, Luther, Wiebe \& Adams, 1988), as a result of the analysis, the explained total variance ratio by three factors is approximately 48 percent. When the eigenvalues of the factors are examined, it is seen that the eigenvalue of Factor 4 is very close to 1 . According to this method, the number of factors must be determined as three due to the rule that the eigenvalue is above 1. In order to find additional proof for number of factors, Horn's Parallel Analysis method was used. Horn's parallel analysis method can be used to determine how many factors the structure has, especially when a structure is defining for the first time. In this method, EFA is performed in parallel in both data by producing artificial data reflecting the characteristics of the real data, and eigenvalues of factors are compared. It is one of the most powerful methods used to determine the number of factors. The structure of the academic jealousy scale is dimensioned for the first time in this study; hence Horn's parallel analysis method is used to determine the number of factors. The results obtained are presented in Table 6. 
Table 6. Results about Parallel Analysis Method

\begin{tabular}{lrrrrr}
\hline & \multicolumn{5}{c}{ Eigenvalue } \\
\hline & Factor 1 & Factor 2 & Factor 3 & Factor 4 & Factor 5 \\
\cline { 2 - 6 } Real data & 4.989 & 2.603 & 1.529 & 0.998 & 0.980 \\
Parallel data & 1.276 & 1.158 & 1.073 & 1.055 & 1.021 \\
\hline
\end{tabular}

The eigenvalues were obtained from Horn's Parallel Analysis Method are presented in Table 6. In this method, simulated data are generated parallel to the real data, which were analyzed with EFA, then the eigenvalues of factors are compared by performing CFA on both data. The stage in which the eigenvalue of the simulated data begins to be higher than the eigenvalue of real data is determined as factor number (Çokluk \& Koçak, 2016; Koçak, Çokluk \& Kayri, 2016). In Table 6, the eigenvalue of the real data is higher than the eigenvalue of the simulated data in the first three factors. As for the fourth factor, the eigenvalue of the simulated data started to take higher value than the eigenvalue of the real data. Accordingly, this method indicates that the number of factors is three.

After the number of factors was determined, factor loadings, cross-loading, serving the same purpose, and item discrimination of 41 items were examined. Items with an item discrimination index above .30 are proper discriminating items (Turgut \& Baykul, 2010). Accordingly, items with item discrimination of less than .30 were excluded from the test. Item with high and close factor loadings in more than one factor is cross-loaded items. Therefore, items with a factor load high in more than one factor were excluded from the test. Finally, the other items were removed from the test by holding one of the items of the same purpose and parallel in the test. Following these procedures, a threefactorial structure was obtained with 19 items. The theoretical compatibility of the items which are in the factors has been the main criterion. When deciding to keep the items on the scale, it was decided by considering the compatibility of the item with the relevant factor, both theoretically and statistically.

After the 3-factor structure of the scale was determined, the stage of the labeling of the factors was started. When the factors were labeled, the studies in the literature were taken into consideration. According to this, when a student's friend scores higher than the student's, is more successful than the student or achieves success, the factor which includes the items which measure the student's angry with himself, the student's self-blame, this situation causes him discomfort was labeled as "Selfdenigration". This dimension corresponds to the self-criticism of Freud's definition of jealousy in Pines (1988), in which the individual blames himself. For example, an item which is "I get angry with myself when I get a lower score than my friend in an exam" is included in this factor. Guerrero and Afifi (1998) state that self-blame and emotional destruction are negative and destructive emotions that may arise during the situation of jealousy. Similarly, Brehm (1992) states too that in the case of jealousy, self-blame, and situation of emotional depression occur. These items point to situations in which the individuals blame themself and create negative feelings towards themself rather than their friend whom they consider to be a competitor. Theoretically, in cases of jealousy, it is possible for individuals to seek the fault in themselves, to get angry, or to blame themselves (Brehm, 1992; Demirtaş, 2004; Guerrero \& Afifi, 1998).

The items in the factor which is named as "Envy" use reflect anger towards the owner of the success that the individual cannot have. Envy refers to individual want to have something that others have, and compare an individual's own quality and quantity with other's, as a result of this, the feeling of individuals reach the point of envy (Anderson, 2002; Demir, 2004; Kim \& Hupka, 2002; Parrott \& Smith, 1993; Pines, 1998). This factor entirely coincides with Freud's concept of envy in Pines (1988). For example, items that "I am grudging my friends who score higher than me in exams" and "I want to prevent my friends from studying" are included in this factor. The items in this factor reveal a sense of envy. Another factor, called "Maturity", is the reaction in which individuals want to have what another person has but turns it into behavior in an insightful or level-headed way, without anger at themselves or their friends. These reactions are named as mature behaviors. Some studies which revealed the relationship between jealousy and age and indirectly maturity (as cited in Bringle \& Williams 1979; Bringle, Roach, Andler \& Evenbeck, 1979; Demirtaş, 2004; Mathes, Phillips, Skowran \& Dick, 1982; Sullivan, 1953) have revealed too that individuals show more mature attitudes in case of possible jealousy as the age increases. Items that "I ask my successful classmates about their 
working techniques ask my successful classmates about their working techniques" and "When my friend is more successful than me, I will be happy for her" are included in this factor and indicate mature reactions.

Item and factor loading distributions of the 19-item three-factor structure, which was determined by considering factor loadings, item discrimination, theoretical structure, are presented in Table 7.

Table 7. Results Related to Distribution of Items to Factors, And Factor Loadings

\begin{tabular}{|c|c|c|c|}
\hline \multirow[b]{2}{*}{ Items } & \multicolumn{3}{|c|}{ Factor Loadings } \\
\hline & Envy & $\begin{array}{r}\text { Self- } \\
\text { denigration }\end{array}$ & Maturity \\
\hline M19. If my friends are more successful than me, it will spoil our friendship. & .852 & & \\
\hline M15. I am grudging my friends who score higher than me in exams. & .819 & & \\
\hline M5. I want to prevent my friends from studying. & 645 & & \\
\hline M18. It makes me angry that someone else achieves the success I cannot. & 630 & & \\
\hline M17. I feel uncomfortable of people who perform better than me at lesson. & .597 & & \\
\hline M10. I do not want my friends to get a master's degree. & .577 & & \\
\hline M16. It makes me angry that someone else answers as true the question I am wrong. & .495 & & \\
\hline M1. I feel uncomfortable being deficient at lessons. & & .772 & \\
\hline M9. I blame myself when I score lower than my friends. & & .708 & \\
\hline M6. It makes me sad that my average is lower than the average of my friends. & & .656 & \\
\hline M7. It makes me ambitious that my friends score higher than me. & & .632 & \\
\hline M3. I like to compete with my friends on lesson topics. & & .606 & \\
\hline M4. When my friends study more than me, I feel irresponsible. & & .559 & \\
\hline M13. I congratulate the people who scored higher than me in the exams. & & & .808 \\
\hline M14. When my friends are more successful than me, I will be happy for them. & & & .787 \\
\hline M12. I ask my friends who are more successful than me to study techniques. & & & .711 \\
\hline M8. I want to be friends with people who are more successful than me. & & & .576 \\
\hline M2. I motivate my friends about to be successful. & & & .552 \\
\hline M11. I want help from my successful friends about the lessons. & & & .464 \\
\hline
\end{tabular}

Varimax method is the most appropriate rotation method when factor loadings of the items are high in a single factor during the EFA stage and when especially some items have a very high factor loading (Kaiser, 1958). The factor loadings are fixed by rotating with the Varimax method by considering this situation. The correlations between the three factors which are presented in Table 7 were calculated as .428 between Envy and Self-denigration, -.376 between Envy and Maturity and -.133 between Maturity and Self-denigration. Item - total test score correlation and Cronbach's Alpha coefficients are presented in Table 8 .

Table 8. Results about Item - Total Test Score Correlations

\begin{tabular}{|c|c|c|c|c|}
\hline \multirow[b]{2}{*}{ Items } & \multicolumn{3}{|c|}{ Item - Total Test Score Correlation } & \multirow{2}{*}{$\begin{array}{r}\text { Cronbach's Alpha } \\
\text { Coefficient }\end{array}$} \\
\hline & Envy & Self-denigration & Maturity & \\
\hline M19 & .537 & & & .769 \\
\hline M15 & .372 & & & .772 \\
\hline M5 & .392 & & & .773 \\
\hline M18 & .549 & & & 771 \\
\hline M17 & .535 & & & .772 \\
\hline M10 & .420 & & & .774 \\
\hline M16 & .461 & & & .774 \\
\hline M1 & & .425 & & 773 \\
\hline M9 & & .430 & & .774 \\
\hline M6 & & .420 & & .773 \\
\hline M7 & & .348 & & .776 \\
\hline M3 & & .391 & & .775 \\
\hline M4 & & .377 & & .775 \\
\hline M13 & & & .529 & .771 \\
\hline M14 & & & .547 & .771 \\
\hline M12 & & & .395 & .773 \\
\hline M8 & & & .397 & .773 \\
\hline M2 & & & .381 & .773 \\
\hline M11 & & & .349 & .776 \\
\hline Total Cronbach's Alpha Coefficient & .840 & .840 & .817 & .779 \\
\hline
\end{tabular}


When Table 8 is examined, it is seen that Cronbach's Alpha internal consistency coefficient was calculated as .779 for the whole scale, .840 for Envy factor, .840 for Self-denigration factor, and .817 for Maturity factor. The correlation coefficient between the data obtained by applying the scale to the third study group with two-week interval was calculated as .89. This coefficient provides evidence for the reliability of the scale in terms of stability. The item - total test score correlation coefficient provides evidence for the discrimination of items (Baykul, 2000). When the item total test score coefficients, which are presented in Table 8, are examined, it is seen that the item discrimination values of items in scale vary between .348 and .549 .

In order to confirm the 19-item 3-factor structure, 153 participants in the fourth study group, were also applied the scales, and CFA was performed to the data obtained from this application.

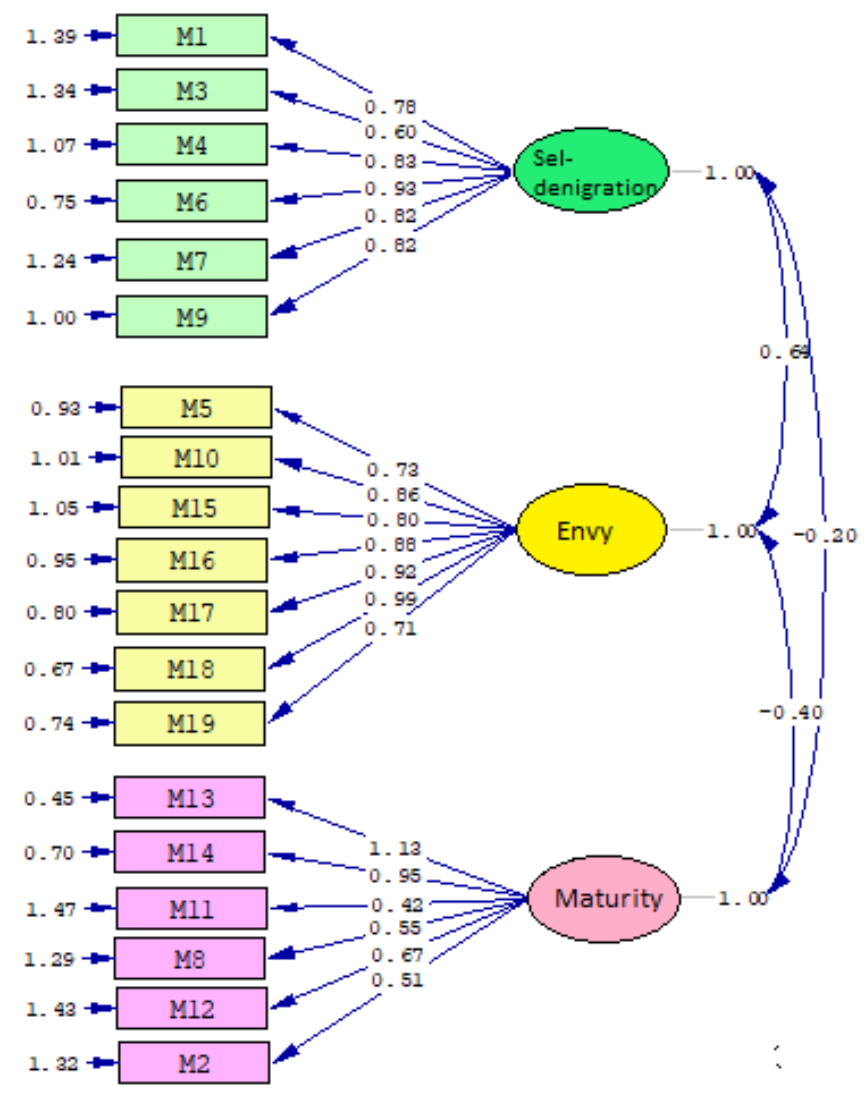

Figure 1. Path Diagram of the Academic Jealousy Scale

The path diagram in Figure 1 was obtained as a result of CFA. Fit indices related to the structure are presented in Table 9.

Table 9. Goodness of Fit Values of the Structure

\begin{tabular}{lrr}
\hline Fit indices & Value & Fit \\
\hline$\chi 2$ & 264.86 & Good \\
$\chi 2 /$ df & 1.77 & Good \\
RMSEA & .07 & Acceptable \\
SRMR & .09 & Acceptable \\
NFI & .96 & Good \\
NNFI & .66 & Acceptable \\
CFI & .88 & Bad \\
GFI & .85 & Bad \\
AGFI & .85 & Acceptable \\
\hline
\end{tabular}


When Table 9 is examined, it is seen that the fit indices except the CFI and GFI indices are within the acceptable or good fit ranges (Bentler \& Bonett, 1980; Çokluk et al., 2012; Jöreskog \& Sörbom, 1982; Stevens, 2002). It is seen that the ratio of the chi-square value to the degree of freedom is 1.77 , and the RMSEA value is .072. The ratio of the chi-square to the degree of freedom is less than 2 indicates a good fit, and an RMSEA of less than .08 indicates an acceptable fit (Tabachnick \& Fidell, 2012). Based on this, the Academic Jealousy Scale which was defined as a three-factor structure with 19 items was accepted as confirmation. It is validity because the majority of the fit indexes were between good and acceptable values.

\section{DISCUSSION and CONCLUSION}

In this research, it was aimed to improve an Academic Scale. For this purpose, 478 university students were reached, and the related structure was defined, reliability and validity indices were determined.

In the development of the scale, a three-factor structure with 19 items was obtained by considering the theoretical structure. The scale explained approximately $48 \%$ of the total variance, and the discrimination indices of items in the scale range from .48 to .549. Cronbach's Alpha method was used to determine the reliability of the scale in terms of internal consistency, and test-retest method was used to determine the reliability of the scale in terms of stability. Cronbach Alpha internal consistency coefficient was found to be .779 for the whole scale, .840 for Envy subfactor, .840 for Self-denigration subfactor, and .817 for Maturity sub-factor. The correlation coefficient between the data, which were obtained by applying the scale to the third study group with two-week intervals is .89 . This coefficient provides evidence for the reliability of the scale in terms of stability. Accordingly, it was concluded that the scale is reliable in terms of stability and internal consistency.

As a result of the CFA to test the three-factor structure which was obtained from EFA, it was found that RMSEA value is .072 , ratio of chi-square to freedom degree is 1.77 , SRMR value is .09 , NFI value is .96, NNFI value is .66, CFI value is .88, GFI value is .85, and AGFI value is .85 . The majority of the indices of model fit indicate that fit is good or acceptable, so it is concluded that the structure is confirmed.

There are statements in the literature that the reactions to be shown differ depending on the level of jealousy. Although these statements are theoretical explanations about jealousy in emotional relations, it is thought that similar reactions will be exhibited in academic jealousy. In the literature, it is stated that the reactions to jealousy are emotional, cognitive and physical (Aune \& Comstock, 1991; DeWeerth \& Kalma, 1993; Guerrero, 1998; Mathes \& Verstraete, 1993; Pines \& Aronson, 1983; Shettel-Neuber, Bryson, \& Young, 1978). It is concluded that the individual's positive or negative cognitive, emotional, and physical responses constitute the concept of academic jealousy with the factors and items in the scale defined in the Academic Jealousy Scale developed. For example, "I want to prevent my friends from studying" in the scale corresponds to a cognitive and negative response, while "When my friends are more successful than me, I will be happy for them" is an emotional and positive response.

When the factors of Envy, Self-denigration, and Maturity that constitute academic jealousy are examined, it can be stated that the responses to be given vary depending on the level of jealousy. The envy factor reflects the individual's negative behaviors. The items in this factor reflect the anger towards the person who has achieved the success that the individual cannot. Envy refers to individual want to have something that others have, and compare an individual's own quality and quantity with other's, as a result of this, the feeling of individuals reach the point of envy (Anderson, 2002; Demir, 2004; Kim \& Hupka, 2002; Parrott \& Smith, 1993; Pines, 1998). For example, an individuals' desire to prevent their successful friends from studying, or getting angry at them reflects the envy subfactor. This factor includes negative emotions as well as behaviors that will adversely affect other people. This situation can be thought of as a physical reaction (Afifi \& Reichert, 1996).

In the sub-factor of Self-denigration, it was concluded that individuals are uncomfortable when someone is more successful than themselves, but as a result of this situation, they blame themselves. 
In the case of jealousy, individuals may get angry with themselves (Brehm, 1992; Demirtaş, 2004; Guerrero \& Afifi, 1998). Guerrero and Afifi (1998) and Brehm (1992) state that self-blame is destructive emotions that may arise in jealousy. This factor fully reflects the individual's self-blame. Pines (1988) names this as self-criticism, but when defining it, one also states that individuals blame themselves. This dimension reveals that individuals blame themselves and not their friend whom they considered to be their rival, looking for a mistake in themselves and get mad at themselves (Brehm, 1992; Demirtaş, 2004; Guerrero \& Afifi, 1998).

The Maturity factor presented that the reaction in which individuals want to have what another person has but turns it into behavior in an insightful or level-headed way, without anger at themselves or their friends. These reactions are called as mature behaviors. The studies which revealed the relationship among jealousy, age and indirectly maturity (by Bringle et al., 1979; Bringle \& Williams 1979; Demirtaş, 2004, Sullivan, 1953; Mathes et al., 1982) reveal that individuals' behaviors in jealousy are related to maturity. In this study, it was also seen that individuals in mature academic jealousy exhibited a mature attitude, preferred to congratulate or sharing experiences, instead of calling guilty.

As a result, it was concluded that the Academic Jealousy Scale, which consists of three factors, Envy, Self-denigration, and Maturity, has 7 items in the Envy factor, 6 items in the Self-denigration factor, and 6 items in the Maturity factor, and the scale and the whole of the factors are reliable and the structure which was defined was confirmed. The concept of jealousy in emotional relations has been frequently investigated in the literature. The development of different scales to measure emotional jealousy formed the basis for the studies on this subject. The most critical obstacle to the study of the concept of academic jealousy is the lack of a scale to measure this feature. It was demonstrated that the developed scale was a valid and reliable scale that could measure academic jealousy in this study. By using the scale in different studies, other concepts related to academic jealousy can be searched, and related theoretical developments can be recorded. This aspect of the study is thought to contribute to the literature.

\section{REFERENCES}

Afifi, W. A., \& Reichert, T. (1996). Understanding the role of uncertainty in jealousy experience and expression. Communication Reports, 9(1), 93-103.

Anderson, R. E. (2002). Envy and jealousy. American Journal of Psychotherapy, 56(4), 455-480. doi: 10.1176/appi.psychotherapy.2002.56.4.455

Aune, K. S., \& Comstock, J. (1991). Experience and expression of jealousy: Comparison between friends and romantics. Psychological Reports, 69(1), 315-319. doi: 10.2466/pr0.1991.69.1.315

Baykul, Y. (2000). Ĕgitimde ve psikolojide ölçme: Klasik test teorisi ve uygulaması. Ankara: ÖSYM Yayınları.

Bentler, P. M., \& Bonett, D. G. (1980). Significance tests and goodness of fit in the analysis of covariance structures. Psychological Bulletin, 88(3), 588-606. doi: 10.1037/0033-2909.88.3.588

Brehm, S.S. (1992). Intimate relationships. New York, NY: McGraw Hill.

Bringle, R. G., \& Williams, L. J. (1979). Parental off-spring similarity on jealousy and related personality dimensions. Motivation and Emotion, 3(3), 265-286. doi: 10.1007/BF01904230

Bringle, R. G., Roach, S., Andler, C., \& Evenbeck, S. (1979). Measuring the intensity of jealousy reactions. Catalog of Selected Documents in Psychology, 9, 23-24.

Buunk, B. P., Angleitner, A., Oubaid, V., \& Buss, D. M. (1996). Sex differences in jealousy in evolutionary and cultural perspective: Tests from the Netherlands, Germany, and the United States. Psychological Science, 7(6), 359-379.

Buunk, B., \& Bringle, R. G. (1987). Jealousy in love relationships. In D. Perlman \& S. Duck (Eds.), Intimate relationships: Development, dynamics, and deterioration (pp. 123-147). Beverly Hills, CA: Sage.

Çokluk, Ö., \& Koçak, D. (2016): Using Horn's parallel analysis method in exploratory factor analysis for determining the number of factors. Kuram ve Uygulamada Eğitim Bilimleri, 16(2), 537-551.

Çokluk, Ö., Şekercioğlu, G., \& Büyüköztürk, Ş. (2012). Sosyal bilimler için çok değişkenli istatistik SPSS ve Lisrel uygulamalart (3rd Ed.). Ankara: Pegem Akademi.

Demir B (2004). Ankara atatürk eğitim ve araştırma hastanesi örneğinde hastane organizasyonu içerisinde hekim-hemşire ilişkisinin çatışma ve güç ilişkileri açısından analizi: Sosyo ekonomik düzeyin, eğitimin, cinsiyet ve çalışma süresinin etkileri (Yayımlanmamış yüksek lisans tezi). Hacettepe Üniversitesi, Sosyal Bilimler Enstitüsü, Ankara. 
Demirtaş, H. A. (2004). Yakın ilişkilerde kıskançlık (bireysel, ilişkisel ve durumsal değişkenler) (Yayımlanmamış doktora tezi). Ankara Üniversitesi, Sosyal Bilimler Enstitüsü, Ankara.

DeSteno, D. A., \& Salovey, P. (1996). Jealousy and envy. In A. S. R. Manstead \& M. Hewstone (Eds.) The blackwell encyclopedia of social psychology (pp. 342-343). Oxford: Blackwell.

DeWeerth, C., \& Kalma, A. P. (1993). Female aggression as a response to sexual jealousy: A sex role reversal? Aggressive Behavior, 19(4), 265-279. doi: 10.1002/1098-2337(1993)19:4<265::aidab2480190403>3.0.co;2-p

Field, A. (2000). Discovering statistics using SPSS for windows. London: Sage Publications.

Friday, N. (1985). Jealousy. New York, NY: William Morrow.

González-Navarro, P., Zurriaga-Llorens, R., Tosin-Olateju, A., \& Llinares-Insa, L. I. (2018). Envy and counterproductive work behavior: The moderation role of leadership in public and private organizations. Int. J. Environ. Res. Public Health 15(7). doi: 10.3390/ijerph15071455

Greenberg, J., \& Pyszczynski, T. (1985). Proneness to romantic jealousy and responses to jealousy in others. Journal of Personality, 53(3), 468-479. doi: 10.1111/j.1467-6494.1985.tb00377.x

Guerrero, L. K. (1998). Attachement style differences in the experience and expression of romantic jealousy. Personal Relationships, 5(3), 273-291. doi: 10.1111/j.1475-6811.1998.tb00172.x

Guerrero, L. K., \& Afifi, W. A. (1998). Communicative responses to jealousy as a function of self-esteem and relationship maintenance goals: A test of Bryson's dual motivation model. Communication Reports, 11(2), 111-122. doi: 10.1080/08934219809367693

Hamamcı, Z. (2002). Ergenlerin yalnızlı düzeyleri ve kişiler arası ilişkilerle ilgili bilişsel çarpıtmaları arasındaki ilişkinin incelenmesi (Yayımlanmamış yüksek lisans tezi), Ankara Üniversitesi, Sosyal Bilimler Enstitüsü, Ankara.

Jöreskog, K. G. \& Sörbom, D. (1982). Recent developments in structural equation modeling. Journal of Marketing Research, 19(4), 404-416. doi: 10.2307/3151714

Kaiser, H. F. (1958). The varimax criterion for analytic rotation in factor analysis. Psychometrika. 23(3). 187200. doi: 10.1007/BF02289233

Karakurt, G. (2001). The impact of adult attachment styles on romantic jealousy (Yayımlanmamış yüksek lisans tezi). Orta Doğu Teknik Üniversitesi, Fen Bilimleri Enstitüsü, Ankara.

Kim, H. J., \& Hupka, R. B. (2002). Comparison of associative meaning of the concepts of anger, envy, fear, romantic jealousy, and sadness between English and Korean. Cross- Cultural Research, 36(3), 229-255. doi: $10.1177 / 10697102036003003$

Kızıldağ, S. (2017). Duygusal kıskançlık ölçeği üniversite öğrencileri formu: Geçerlik ve güvenirlik çalışmaları. Journal of Measurement and Evaluation in Education and Psychology, 8(1), 146-157. doi: 10.21031/epod.302673

Kızıldağ, S., \& Yıldırım, İ. (2017). Eş duygusal kıskançlık ölçeği’nin geliştirilmesi. Kuram ve Uygulamada Ĕ̈itim Bilimleri., 17(1), 175-190.

Koçak, D., \& Çokluk-Bökeoğlu, Ö. (2017). Kayıp veriyle baş etme yöntemlerinin model veri uyumu ve madde model uyumuna etkisi. Eğitimde ve Psikolojide Ölçme ve Değerlendirme Dergisi, 8(2), 200-223. doi: 10.21031/epod.303753

Koçak, D., Çokluk, Ö., \& Kayri, M. (2016): Faktör sayısının belirlenmesinde MAP testi, paralel analiz, K1 ve yamaç birikinti grafiği yöntemlerinin karşılaştırılması. YYÜ Eğitim Fakültesi Dergisi, 11(1), 330-359. https://dergipark.org.tr/tr/download/article-file/253575 adresinden elde edilmiştir.

Lewin, K. (1948). Resolving social conflicts. New York, NY: Harper.

Massé, L., \& Gagné, F. (2002). Gifts and talents as sources of envy in high school settings. Gifted Child Quarterly, 46(1), 15-29. doi: 10.1177/001698620204600103

Mathes, E. W., \& Severa, N. (1981). Jealousy, romantic love, and liking: Theoretical considerations and preliminary scale development. Psychological Reports, 49(1), 23-31. doi: 10.2466/pr0.1981.49.1.23

Mathes, E. W., \& Verstraete, C. (1993). Jealous aggression: Who is the target, the beloved or the rival. Psychological Reports, 72(3), 1071-1074. doi: 10.2466/pr0.1993.72.3c.1071

Mathes, E. W., Phillips, J. T., Skowran, J., \& Dick, W. E. (1982). Behavioral correlates of the interpersonal jealousy scale. Educational and Psychological Measurement, 42(4), 1227-1231. doi: 10.1177/001316448204200432

Mead, M. (1977). Jealousy: Primitive and civilized. In G. Clanton \& L. G. Smith (Eds.), Jealousy (pp. 115-127). Englewood Cliffs, NJ: Prentice Hall.

Parrott, W. G., \& Smith, R. H. (1993). Distinguishing the experience of jealousy and envy. Journal of Personality and Social Psychology, 64(6), 906-920. doi: 10.1037//0022-3514.64.6.906

Pfeiffer, S. M., \& Wong, P. T. (1989). Multidimensional jealousy. Journal of Social and Personal Relationships, 6(2), 181-196. doi: 10.1177/026540758900600203 
Pines, A.M. (1988). Keeping the spark alive: Preventing burnout in love and marriage. New York, NY: Free Press.

Pines, A. M. (1998). Romantic Jealousy: Causes, symptoms, cures. New York, NY: Routledge.

Pines, A. M., \& Aronson, E. (1983). The jealousy question scale. Psychological Reports, 50, 1143-1147.

Pines, A. M., \& Bowes, C. F. (1992). Romantic jealousy. Psychology Today, 25(2), 48-56. Retrieved from https://www.psychologytoday.com/us/articles/199203/romantic-jealousy

Rentzsch, K., Schröder-Abé, M., \& Schütz A. (2015). Envy mediates the relation between low academic selfesteem and hostile tendencies. Journal of Research in Personality, 58, 143-153. doi: 10.1016/j.jrp.2015.08.001

Salovey, P., \& Rodin, J. (1986). Differentiation of social-comparison jealousy and romantic jealousy. Journal of Personality and Social Psychology, 50(6), 1100-1112. doi: 10.1037/0022-3514.50.6.1100

Scherer, R. F., Luther, D. C., Wiebe, F. A., \& Adams, J. S. (1988). Dimensionality of coping: Factor stability using the ways of coping questionnaire. Psychological Report, 62(3), 76-770. doi: $10.2466 /$ pr0.1988.62.3.763

Shettel-Neuber, J., Bryson, J. B., \& Young, C. E. (1978). Physical attractiveness of the "other person" and jealousy. Personality and Social Psychology Bulletin, 4(4), 612-615. doi: $10.1177 / 014616727800400424$

Spielman, P. M. (1971). Envy and jealousy: An attempt at clarification. Psychoanalytic Quarterly, 40(1), 59-82. doi: 10.1080/21674086.1971.11926551

Stevens, J. P. (2002). Applied multivariate statistics for the social sciences. New Jersey, NJ: Lawrance Erlbaum Associates, Inc.

Sullivan, H. S. (1953). The interpersonal theory psychiatry. New York, NY: Norton.

Tabachnick, B. G., \& Fidell, L. S. (2012). Using multivariate statistics. Boston, MA: Allyn \& Bacon/Pearson Education.

Turgut, M. F., \& Baykul, Y. (2010). Ĕ̌itimde ölçme ve değerlendirme. Ankara: PegemA.

White, G. L. (1981). Relative involvement, inadequacy, and jealousy: A test of a causal model. Alternative Lifestyles, 4(3), 291-309. doi: 10.1007/BF01257942 